\title{
The Sustainability Stimulus of Malaysian Seaport Cluster toward Competitive Vigilance: The Total Quality Management (TQM) Approach
}

\author{
Mohamad Rosni Othman', Noor Azwa Noralam², Jagan Jeevan², Mohd Saiful Izwaan Saadon ${ }^{4}$, \\ Tan Owee Kowang ${ }^{5}$
}

${ }^{1,2,3,4}$ Faculty of Maritime Studies, Universiti Malaysia Terengganu, Malaysia.

${ }^{5}$ Azman Hashim International Business School, Universiti Teknologi Malaysia, Malaysia.

Corresponding author email: rosni@umt.edu.my ${ }^{* 1}$

Article History: Received: 10 November 2020; Revised: 12 January 2021; Accepted: 27January 2021;

Published online: 05April 2021

\begin{abstract}
The quality management is primarily a commercial action, interaction between strategic business components and management practices and supported by seaport users in the seaport cluster. With the progressive approach, a conceptual of seaport quality can be installed into the seaport activities to stimulate the seaports to create and sustain competitive advantage by increasing their ability to respond tousers' needs through the quality improvement of seaport services as logistics platforms. The Total Quality Management (TQM) can be used to improve the responsiveness of seaport cluster products and services from upstream entities to downstream entities. The quality management focuses on: to satisfaction of customers; reduce cost; improve productivity; and, to optimize the seaport operations. This issue has become apparent within theseaport cluster, whilethe influence of quality on customer perceptions and consumption behavior has become a major factor affecting the end user choice of seaports. Although that quality management provides approaches to achieve such objectives, a limited number of seaports have developed quality-oriented approaches. This paper explores issues related to the total quality management within the seaport cluster, this paper also reviewing on the current situation at Malaysian seaports that are currently using the ISO for improving the organizational performance. A conceptual of seaport quality will be introduced as a framework for excellence for the seaport cluster and may provide the best strategic approach for the seaports at present and in the future. This paper will provide practitioners and policy makers with an indication of the applicability of the quality culture in the seaport cluster.
\end{abstract} Keywords: Seaport Cluster, ISO, Total Quality Management, Quality Culture.

\section{Introduction}

Malaysia is surrounded by seas and depends heavily on the maritime sector to facilitate much of its trade and generate economic activities. Malaysia enjoys a strategic location along major shipping trade lanes, namely the Straits of Malacca and South China Sea, and draws its hydrocarbon energy riches and much of its source of protein from the seas. In 2014, total trade was RM1.45 trillion. $98.4 \%$ of Malaysian trade is carried by sea. ${ }^{1}$ It carried 539,233,000 tonnes of cargo in and out of Malaysia. It employs 337,000 people either at sea or on shore. ${ }^{2}$ Container throughput at Malaysia's ports was 22,373,309 (TEUs). The number of ships that visited Malaysian seaports was $61,668^{3}$ and increasing every year.

Seaports or Ports, according to Thai and Grewal (2005) as one of the links between different modes of transportation within the logistics chain, have special essential essence since their efficiency and competitiveness will certainly have an impact on the chain, and hence the national and regional economic. Moreover, it is believed that the growth and development of a country is influenced by the transferring of international trade between countries through its international transportation especially seaport (Tahar and Hussin, 2000; Powel, 2001; Southal, 2005; Branch, 2007). The large volume of goods or cargo only can be carried via ocean transportation not just because the price charged very competitive compared with the other transportation but also the location between countries.

The attractiveness of seaports is no longer based on strategic location but on the provision of efficient, prompt and quality services, excellent logistics and land transport infrastructure and sea transport network. Seaports have become commercial centers and manufacturing gateways.

${ }^{1} \mathrm{EPU}(2014)$. Strategy Paper 14: Unleashing growth of logistics and enhancing trade facilitation. http://rmk11.epu.gov.my/pdf/strategy-paper/Strategy\%20Paper\%2014.pdf. Last accessed 21 April 2016.

${ }^{2}$ MASA (2014). The competitiveness of the Malaysian shipping industry: Way forward.

${ }^{3}$ Ministry of Transport (2015). Transport Statistics 
In themaritime ecosystem, seaports play a vital role for the purpose of achieving comparative advantages in the international market if they can manage the cargo and containers effectively and efficiently and able to prevent any unwanted consequences. Thus, constant evaluations need to be done by port operators over its operations or any processes related to providing, marketing, and selling of services to the users. Hence, it can be said that by improving the quality of seaport system and activities from any angle could improve the countries economic and indirectly improve the income of a country to a higher level.

In addition, with current trend of alliances of shipping liners, for instance, Mearsk-Sealand and Evergreen having an alliance with the port of Tanjung Pelepas (Kleywegtet al., 2002) and the opening of new terminals by Dubai port operator at the Saigon Premier Container Terminal in Ho Chi Minh, Vietnamhas rapidly accelerated the maritime activities at those particular places. The drastic increase in the ocean transportation has made seaport authorities and operators to cope as well as to adapt the current situations and development in seaport industry especially in handling the increasing volume of international trade. Therefore, the seaport authorities especially, have to make sure the services provided to its users are appropriate with the market needs. With the very good quality services provided, it will help seaports to increase or enhance its overall performance by adoption of the Total Quality Management (TQM).

\subsection{The Principle of TQM}

TQM is the product of a complexmixture of strategic business components and management practices. Although quality has recently received significant attention, both qualitative and/or qualitative results relating quality management approaches to the seaport cluster are only a few. The main approaches related to quality have developed (Oakland, 1989; Pun et al, 1999) from inspection, statistical process control, and quality assurance, to Quality Management Systems(QMS) and Total Quality Management (TQM). The abovementioned approaches were building upon the previous one through theintroduction of new methods and/or practices. Nowadays emphasis is placed on prevention (quality assurance \& quality standards) while continuous improvement quality approaches still remain a challenge for many business sectors.

TQM is a management philosophy concerned with people and work processes that focuses on customer satisfaction and improves organizational performance. TQM requires an enterprise to systematically energize, manage, coordinate, and improve all business activities in the interest of customers. TQM requires improvements throughout an organization to reduce waste and rework, to lower costs, and to increase productivity. Quality is no longer merely the province of service inspectors, the director of quality assurance, or the work supervisor. It can be defined, measured, and achieved, but such achievement requires that quality is built into all work processes and is understood and applied by all employees. Everyone is responsible for TQM, especially senior management; all employees are involved in solving problems and improving performance. Like many so-called "new ideas," the components of TQM are not all new. Rather, TQM is new because it embraces and enjoins many existing management and organizational philosophies. TQM has its roots in many disciplines, including economics, industrial engineering, social psychology, mathematical statistics, and management science. ${ }^{4}$

Besides that, another opinion from the expertise from the Hyde (1992) TQM views an organization as a collection of processes. It maintains that organizations must strive to continuously improve these processes by incorporating the knowledge and experiences of workers Yusr et al., (2017). The simple objective of TQM is "Do the right things, right the first time, every time." TQM is infinitely variable and adaptable. Although originally applied to manufacturing operations, and for a number of years only used in that area, TQM is now becoming recognized as a generic management tool, just as applicable in service and public sector organizations. There are a number of evolutionary strands, with different sectors creating their own versions from the common ancestor. TQM is the foundation for activities, which include commitment by high level management and all employees, Meeting customer requirements, Reducing development cycle times, Just in time/demand flow manufacturing, Improvement teams, Reducing product and service costs, Systems to facilitate improvement, Line management ownership, Employee involvement and empowerment, Recognition and celebration, Challenging quantified goals and benchmarking, Focus on processes / improvement plans and Specific incorporation in strategic planning, this shows that TQM must be practiced in all activities, by all personnel, in manufacturing, marketing, engineering, R\&D, sales, purchasing, HR, etc.

\footnotetext{
${ }^{4}$ Stephen J. Andrle (1994), Total Quality Management in Public Transportation
} 
${ }^{5} \mathrm{TQM}$ is a management of philosophy concerned with people and process that focused on customer satisfaction and improves organizational performance. According to the Stephen, TQM requires an enterprise to systematically energize, manage, coordinate and improves all business activity in the interest of customers (1994). According to history of TQM, it was started on 1920's century whereby some of the first seeds of quality management were planted as the principles of scientific management swept through U.S. industry. Businesses clearly separated the processes of planning and carrying out the plan, and union opposition arose as workers were deprived of a voice in the conditions and functions of their work. The Hawthorne experiments in the late 1920s showed how worker productivity could be impacted by participation. At 1930's, Walter Shewhart developed the methods for statically analysis and control of quality. While in 1950's, W. Edwards Deming taught methods for statistical analysis and control of quality to Japanese engineers and executives. This can be considered the origin of TQM. Joseph M. Juran taught the concepts of controlling quality and managerial breakthrough. Armand V. Feigenbaum's book Total Quality Control, a forerunner for the present understanding of TQM, was published. Philip B. Crosby's promotion of zero defects paved the way for quality improvement in many companies. At 1968, The Japanese named their approach to total quality companywide quality control. It is around this time that the term quality management systems arise. The Kaoru Ishikawa's synthesis of the philosophy contributed to Japan's ascendancy as a quality leader.

Nowadays, the Total Quality Management Approach was in line with the name of the management philosophy for the systematic approach to manage the organizational quality. Besides that, currently the Total Quality Management Approach is using the ISO 9000 series and quality award such as Deming Prize and the Malcolm Baldridge National Quality Award specify principles and the processes that comprise TQM. ${ }^{6}$

\subsection{Seaport Development}

According to the seaport transformation there was fourth generation for the seaport development. The first generation refers to seaports before 1960 (UNCTAD 1992). In this generation, seaports were the only interchange point between sea and land. In this first generation, the functions of a seaport were limited to the basic activities of loading, discharging, handling, storage and services around navigation, quay and waterfront area. The main cargos handled in the first generation were break bulk (UNCTAD 1992; 1998). Referring for the second generation which was from the 1970s to 1980s, there were starting expanded their activities and started to think of the customer need. In this activities there was provided the activities such as a ship chandler and ship repairs. There were expanded from the basic cargo to the ship industrial and commercial services (Beresford et al. 2004). It was some value added services and can give the customer satisfaction.

As for the third generation emerged between 1980 and 1990 (UNCTAD 1992). Seaport activities expanded to incorporate logistics and customer services (UNCTAD 1992 and Woo et al. 2009). Under the pressure of business competition, increasing demand from seaport users and the bargaining power of seaport service providers, seaports became a node in the distribution network (Beresford et al. 2004; World Bank 2007). For the reference in the final report on WORKPORT (1989-1999) submitted to the European Commission, Beresford et al. (2004) define the decisive factors affecting the seaports from 1980s to 1990s as an expansion of seaport activities into logistics, distribution centres with high value-added services and globalisation of seaport communities. In this generation there were transformed from the traditional cargo to the high value-added cargo and information distribution, and also land based logistics activities. Focusing on this activities make this generation enhanced of their quality of services.As related to enhance the quality services, in this third generation also applying for the ISO series and the latest in place is the ISO, which is practically applied in many seaports. For example, ISO 9001:2008 was provides a set of standardised requirements for quality management system (ISO 2009). ISO systems that the organisation concerned should develop its own formal documented processes and follow these processes. The processes should be formally recorded and be ready for audit and accreditation by an independent quality system certification body (ISO 2009) such as Bureau Veritas, American Society for Quality, ABS Quality Evaluation and Det Norske Veritas (VINAMARINE 2008). As the ISO series is largely dependent upon documentation, it does not inspire a quality culture within an organisation.Fourthly, the position of seaports in the supply chains is indirectly addressed in the literature, which examined the importance of stakeholder management in seaports and the environmental strategy adopted by the seaports, such as the study of Dooms and Verbeke (2007) and Haezendonck and Dooms (2007). These authors suggest that stakeholder management can be usually adopted in the long term and daily activities. The researchers argued that

\footnotetext{
${ }^{5}$ Hyde, A. (1992). "The Proverbs of Total Quality Management: Recharting the Path to Quality Improvement in the Public Sector." Public Productivity and Management Review, 16(1), 25-37.

${ }^{6}$ Adapted from The Certified Manager of Quality/Organizational Excellence Handbook, pages 290-291.
} 
green management in seaports is critical and seaports can no longer be considered in isolation, but in the supply chain context. This argument is also favoured in the study by Haezendonck and Dooms (2007) who argue that seaports should focus on sustainable strategic decisions and actions, including promoting environmentally friendly transport methods for hinterland traffic. These arguments support the notion that safety, security and environmental management should be an integrated part of a seaport's management policies, and should be designed and implemented in conjunction with other partners.

Nowadays, the changes of development Seaport, Inland port or known as a Dry Port are also play the importance role of the performance or development of seaport port. As originally conceived, a 'dry port' was defined as an inland terminal to and from which shipping lines could issue their bills of lading, with the concept being initially envisaged as applicable to all types of cargo (UNCTAD, 1982) ${ }^{7}$. In both theory and practice, however, the concept has evolved not only to be closely associated with the rapid expansion of containerisation and related changes in cargo handling (UNCTAD, 1991) ${ }^{8}$, but also to be applied in a variety of different contexts having the common characteristic of relating simply to 'a place inland that fulfills original port functions' (Cullinane and Wilmsmeier, 2011) ${ }^{9}$

According to Dr. Jean Paul Rodrigue and Dr. Theo Notteboom (2013), Inland Port can described as a rail or a barge terminal that is linked to a maritime terminal with regular inland transport services. An inland port has a level of integration with the maritime terminal and supports a more efficient access to the inland market both for inbound and outbound traffic. This implies an array of related logistical activities linked with the terminal, such as distribution centres, depots for containers and chassis, warehouses and logistical service providers. Since the inland terminal is essentially an extension of some port activities inland, the term "dry port" has gained acceptance inland port. Therefore, the concept of inland port is polymorphic, implying that it can have different meaning depending on its location, connectivity, role and function. ${ }^{10}$

Due to the function of the importance of the Dry Port, we can see that Seaport and Dry Port cannot be separately because of there are related each other. To be a competitive port, the dry port concept must be based on a seaport directly connected with inland intermodal terminals where goods in intermodal loading units can be turned in as if directly to the seaport by Johan Woxenius, Violeta Roso, Kenth Lumsden (2004) ${ }^{11}$. According to RodrigendNotteboom (2008) also argue that seaport and inlands are adopting a more active role within a supply chains in that terminal are being used as a distribution centres ${ }^{12}$. This is similar to the view of Notteboom and Wilkeman who are argues that a successful seaport should be constantly adopting new roles in order to copes with the changing of market environment.

Thus, this paper aims at identifying the development of Malaysian seaport by analysing the growth of cargo volumes during the last three decades and the capacity constraints encountered by major Malaysian seaports. This study also reveals the ability of Malaysian seaports' capacity to accommodate increasing trend in cargo volume in this region. This study provides relevant strategies for seaports to improve its capacity constrain by improving its quality management in infrastructure and facilities. This paper also discuss how a seaport can increase its quality management toward performance and reduces the seaport congestion in a very fierce competition and how competitive factors such as physical facility, technology adoption, and ownership structure (privatization) that related to the quality are able to increase and enhance the efficiency and effectiveness of the seaport, attract more seaport users and in turn improve the performance of the seaport.

The results of this research offer directions for the future capacity development strategies of seaports to move simultaneously with trade growth and providing significant strategies for quality management in capacity utilization toward quality culture in seaport cluster. Therefore, the prediction of the cargo volume in Malaysian

\footnotetext{
${ }^{7}($ UNCTAD, 1982)

${ }^{8}$ (UNCTAD, 1991)

${ }^{9}$ Cullinane, K.P.B. and Wilmsmeier, G. (2011) The contribution of the dry port concept to the extension of port life cycles. In: J.W. Böse (ed.) Handbook of Terminal Planning, Operations Research Computer Science Interfaces Series, Vol. 49. Heidelberg, Germany: Springer, pp. 359-380.

${ }^{10}$ Dr. Jean-Paul Rodrigue and Dr. Theo Notteboom,(2013), The Georgraphy Of Transport System : Inland / Dryport

11 Johan Woxenius, Violeta Roso, Kenth Lumsden (2004), The Dry Port Concept - Connecting Seaports with their Hinterland by Rail.

${ }^{12}$ Rodrigue and Notteboom (2008), The terminalisationof supply chain," in Proceedings of the LAME 2008, Conference, Dailan China.
} 
seaports, reducing seaport congestion and competitive factors are important to address the requirement for the quality management.

\section{Malaysian Seaport Cluster}

The concept of clusters is related to the "competitiveness" of industries and of nations as described below:

Clusters are a geographically proximate group of interconnected companies and associated institutions in a particular field linked by commonalities and complementarities. Clusters encompass an array of linked industries and other entities important to competition . . . including governmental and other institutions - such as universities, standard setting agencies, think tanks, vocational training providers and trade associations(Porter 1998).

Fundamentally, a cluster is an internationally recognizable competitive advantage in a particular sector of industry (Porter, 1998). Roelandt et al. (1999) have shown that, the cluster may encompass intensive links and alliances with various institutions such as universities, research institutions, public authorities, consumer organizations, and so on.In general, it is known that the management of the maritime sector is difficult due to firstly, the definition of what constitutes in the maritime industries and, secondly, the large fragmentation of the different sectors involved. Seaport cluster model demonstrated the general distribution of the seaport activities covering three main maritime sectors: Maritime Services, Shipping and Maritime Equipment and Suppliers (Fig. 1).

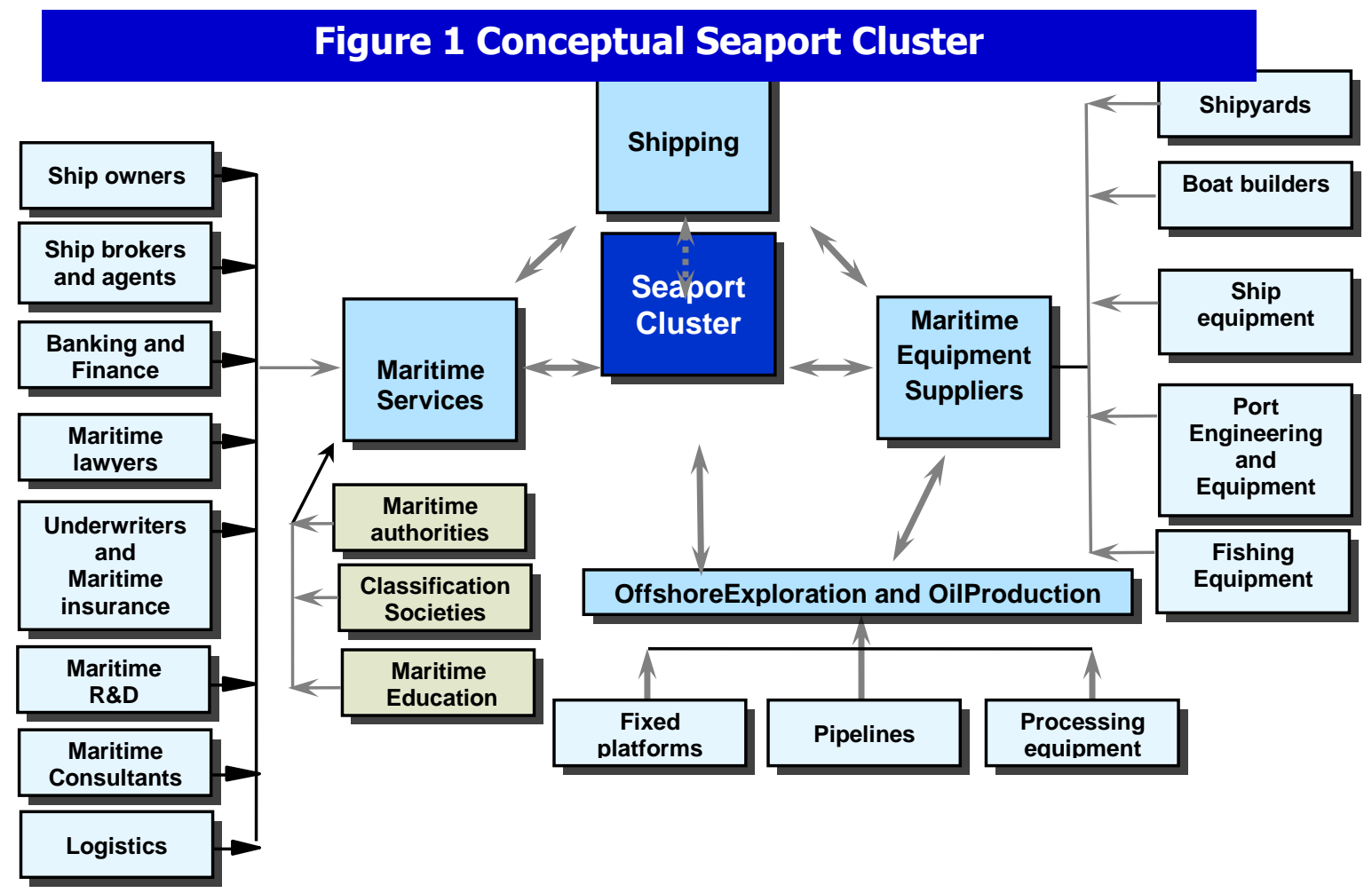

Figure 1. Conceptual Seaport Cluster

Source: Authors

Malaysia has $0.44 \%$ of the world's population in 2013, represents $0.49 \%$ of the world's economy, yet accounts for $1.07 \%$ of world seaborne transportation. Malaysia GDP 2013 was 5.0\%, Malaysia is also external competitive, ranking $12^{\text {th }}$ (out of 135 economies) in year 2013 (Source: http://www.worldbank.org/)

The rapid growth of globalization phenomenal and the growth in international trade recently have had a huge impact in the seaports all over the world. This is followed with the boom of containerization usage in transporting goods via ocean among countries (Chudasama, 2009; Yeo et al., 2007; Le-Griffin and Murphy, 2006; Notteboom, 2006; Tengku, 2003). These situations have consequently demanded for quality management toward efficient maritime facilities and activities for global logistic services particularly in the seaport cluster. 
Furthermore, with the emerged of emerging countries in Asia region(e.g. China) and Americas region (e.g. Brazil) have an enormous impact towards seaport cluster. One of the impacts can be seen from the demand perspective. With the opening markets to foreign companies and massive benefits offered, many Multinational Companies (MNCs) make use of this opportunity to expand their businesses. This situation leads the companies to produce its production in large volume and indirectly the economics of scale can be obtained which their can sell the products at the lower price. As a result, the demand for the transferring goods via ocean dramatically increased. On the other hand, these situations actually have another issue, which is congestion, and it would lead to inefficiency and ineffective operation at seaport(Tengku, 2003; Yeoet. al 2007).

According to Brodie (2006) congestion can be define as to the accumulation of ships at a port to the extent that ships arriving to load or discharge are obliged to wait some days, in extreme cases, weeks for a vacant berth so as to loading or discharging their cargo. Many ships have to wait at anchorage for a certain period in order to wait for their turn to be served at a vacant berth. There are many reasons that lead to seaport congestion. Undeniable, some of the factors (such as severe weather and strikes) are not under the control of the seaports but the other factors (such as the failure and obsolete of handling equipments, the state-of-art technology and etc) still can be controlled by the seaport authority or seaport operator, however the problem still arise. Why this problem keeps continuing? Tongza (2009) stated, without the adequate infrastructure especially the quality of crane and quality and effectiveness of information systems definitely have bad consequences. One of the bad consequences isthe seaport users will look for other seaports services, if the seaport authority or seaport operators failed to manage the high volume of cargo efficiently and effectively. Fourgeaud(1993) also agreed which stated that the poor performance in seaport is due to the poor qualityorganization of handling and storage operations and maintenance at seaport. So, definitely, aquality and adequate infrastructures play a significant role in the performance of seaport in which it reduces maritime transport cost by avoiding congestion and ship waiting time, and finally the movement of freight can be fasten and help ship achieve the economics of scale.

Furthermore, according to Chudasama (2009), there are limited resources of literature that have been discussed specifically on seaport performance evaluation and have rarely considered the role of seaport's physical facility as a significant indicator contributing to overall performance.In addition, Kia et al., (2000), stated the lack of information technology at terminal operations leading to port congestion and operational inefficiency at terminal is the main consequences of the poor technology used at seaport. Meanwhile, the involvement of private sectors in seaport cluster are seldom discuss and this is supported by Tongzaet al., (2005) stated to date, there is little attention has been given to the effect of seaports' ownership structure on seaport efficiency in Asia region particularly.

Some of the studies that have been conducted on the effect of ownership structure towards performance show that the concept of privatization adopted by seaports has different results. Some studies argued the involvement of private sector in seaport industry doesn't have a significant impact (Notteboom, et al., 2000 and Liu, 1995) and some of them claimed that the involvement of private sectors have a great impact to seaport performance (Cullinane et. al 2002 and Estacheet al., 2002).

The congestion, delays of trade, increasing costs, inefficient and ineffective, not competitive, low turnaround time of vessel, high ship waiting time and queuing of vessels at anchorage (Yeoet al., 2008, Notterboom, 2006 and Tengku, 2003) will give a bad reputation and image of seaport operators or seaport authorities and it will have impacts to seaports users (such as carriers, shippers and freightforwarders). As consequences, many seaport users move or changeto the seaports of calls that are able to provide and give the better operationalize system and services(Yeo et al., 2007). As an example, Busan Port in South Korea, which is ranked third largest container handling volume in the world in 2002, is suffered from the severe sea access congestion and as a result, many shipping lines reduced their seaport of call at Busan Port. When this scenario take place, the percentage of seaport of calls will decrease and it's has a huge effect onseaport performance. Yeo et al., (2008), indicates that the seaport congestion is one of the components that determined the competitiveness of a seaport. The good level of turnaround time will help seaports to increase and enhance the performance at a better level. However, the efficiency factors for each country in order to enhance the port performance definitely vary from one country to another and this supported by Chudasama (2009).In general, there is ample of literature about the performance of seaport from the port authority and seaport operator perspective. However, there is more attention has been given to the seaport performance from the perspective of port users based on the quality management approaches. Seaport users according to Tongza (2009) really stressed out the important of seaport efficiency in order to make Asiaseaport of call. Hence,the efficiency of the seaport is closely related with the quality of the seaport. He added, that the speed and productivity is the main ingredients that will be looked and considered by seaport users in order to use the services provided by seaport authorities or operators in order to transferring the cargo or containers. If the seaport fails to provide as what the seaport users requests this will reduce the seaport of calls 
and slowly affect the performance of seaport. Therefore, TQM in the seaport cluster is important to ensure the seaport is in competitive advantage.

\subsection{Current Situation of Malaysia Seaport}

Malaysia's strategic geographical proximity to main trunk route through Malacca strait brings numerous opportunities in the international maritime market. One of the major implications of the extensive growth of Malaysian seaports is the provision of quality management and adequate quality seaport capacity to ensure that the Malaysian maritime industry, especially the seaports sector, is prepared to move ahead simultaneously with globalisation. The Malaysian seaport sector has been subjected to government regulation and national policy on infrastructure development. The expansion of seaports is therefore determined by the decisions made by the government at a national level and subject to national planning policy. Over the last decades seaport capacity expansion was continuous but with a five-year production lag. Since 1966, every five years the Malaysian Plan contributes to the capacity development of Malaysian seaports based on TEU performance (Tenth Malaysian Plan, 2011).

The strategy implemented by the government to invest in seaport capacity prevents surplus investment in capacity, which would then trigger an over-capacity problem. Therefore the seaport capacity expansion of major ports demonstrates a clear pattern that every five years additional capacity is added to the port sector. Figure 2 shows total Seaport Capacity in TEU (PCTEU) of major Malaysian seaports and Total TEU (TTEU) growth for the period 1990-2012.

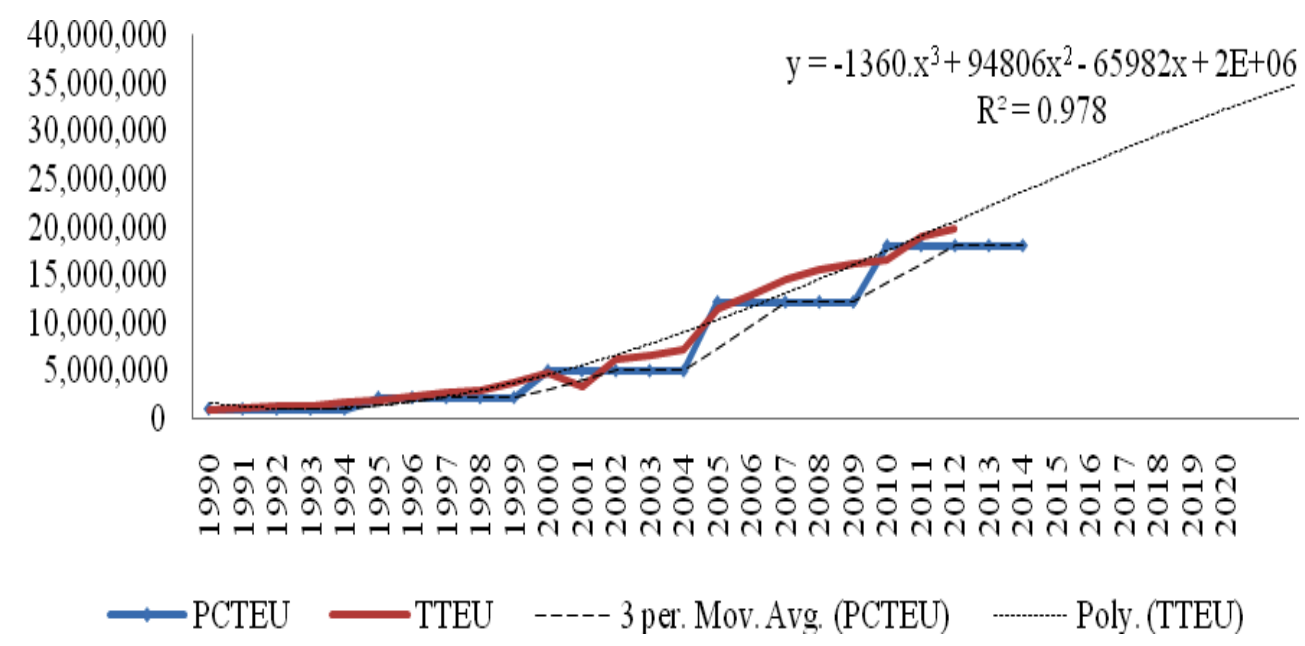

Figure 2.Total TEU growth and total port capacity of major Malaysian ports 1990-2012 Source: Authors

The trend line fitted to data on the total TEU of the five major seaports demonstrates an increasing growth over the next 10-year period. The change in total TEU due to the change in one year (that is ' $x$ ' in the regression equation) on average would be around 1.4 million $[=-1360.3(1) 3+94806(1) 2-659826(1)+2 \mathrm{E}+06]$ for all Malaysian seaports. The trend line forecast (polynomial) is a good model fit by considering a very high $\mathrm{R}$ square value $(\mathrm{R} 2=0.9788)$. The total port capacity of the five Malaysian ports remains at approximately $18,000,000$ TEUs in the next three-year period. The challenge is whether the ports are able to accommodate such an everincreasing TEU volume within the ports. Thus, implementation of the TQM to seaports cluster is crucial to enhance the seaport performance.

Major seaports in the country have been the gateways to international trade and over the years ports have developed and modernised to reach the world-scale competitive international port league. The quality of the seaport cluster is a primary concern of port users, both shipping lines and shippers. Providing high quality toward efficient and reliable port services is a key determinant in the port choice of shipping lines. Therefore maintaining such a high standard of quality in seaport services is a challenge for seaport management. With increasing seaport trade, a seaport faces limitation of seaport capacity, long cargo dwelling times and long ship turnaround times unless seaport management continues to improve the quality standards towards latest technology adoption and quality seaport physical capacity in line with seaport volume. 
High volumes of seaport trade prompt seaport management to take initiatives towards expanding seaport capacity. Within a centralised seaport management system where the public sector has the sole discretion of making investment decisions on seaport infrastructure, seaport capacity expansion demonstrated a clear pattern of growth. Figure 3, illustrates that capital allocation for the Malaysian seaport sector has been on the rise and, during 2014 and 2015, it will be significantly increased. The amount of investment in seaport capacity increased almost six times from 1990 to 2005. In contrast, the volume of capacity expenditure shrank from 2006 to 2010 compared to previous years.

These phenomena occur because the seaport capacities are adequate to comply with the number of cargos in that time period as depicted in Figure 3, to achieve competitive vigilance during this time the TQM should be adopted due to the majority of the major Malaysian ports are underutilize (See Table 2).

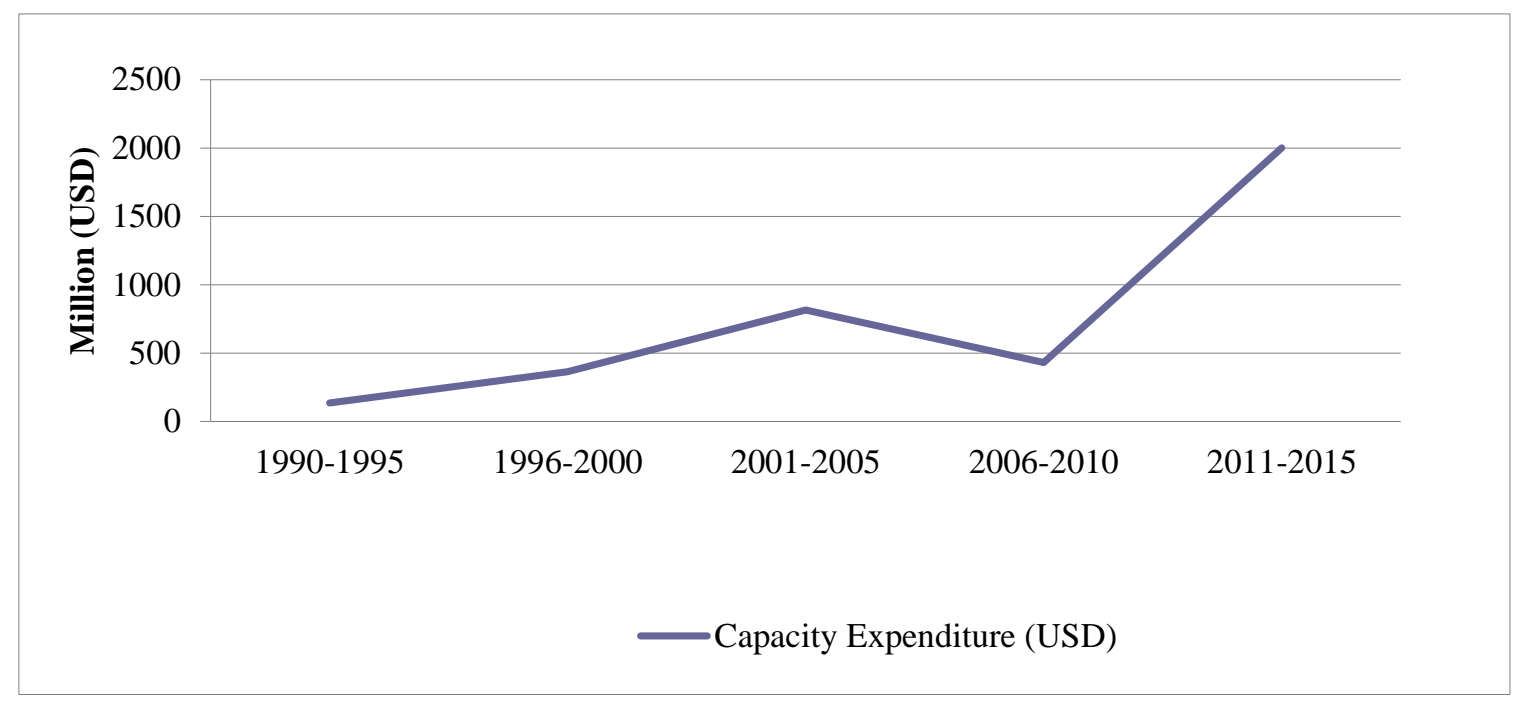

Figure 3.Total cost allocation of port capacity 1990-2013

Source: Tenth Malaysian Plan (2011)

Table 1. Indicator of Berthing Capacity in Malaysia Major Seaport

\begin{tabular}{|l|c|c|c|c|c|}
\hline $\begin{array}{c}\text { Malaysian } \\
\text { Seaport }\end{array}$ & $\begin{array}{c}\text { Average Ship } \\
\text { Calls per Year } \\
\mathbf{( 2 0 1 0 - 2 0 1 5 )}\end{array}$ & $\begin{array}{c}\text { Average Ship } \\
\text { Calls per Day } \\
\text { (A) }\end{array}$ & $\begin{array}{c}\text { Berth } \\
\text { Length } \\
\text { (Meter) }\end{array}$ & $\begin{array}{c}\text { Berth Capacity } \\
\text { Ship / Day (B) }\end{array}$ & $\begin{array}{c}\text { Berth } \\
\text { Underutilized by } \\
\text { No. of Ship Per } \\
\text { Day (A-B) }\end{array}$ \\
\hline Port Klang & 17,031 & 47 & 18,600 & 53 & -6 \\
\hline Penang & 6,505 & 12 & 16,200 & 6 & -3 \\
\hline Johor & 4,350 & 7 & 4,474 & 15 & -7 \\
\hline Kuantan & 2,384 & 13 & 4,013 & 14 & -4 \\
\hline $\begin{array}{l}\text { Tg. } \\
\text { Pelepas }\end{array}$ & 4,812 & 5,040 & & 17 & \\
\hline
\end{tabular}

Source: Ministry of Transport, Malaysia.

In the Tenth Malaysia Plan (2011-2015), the Malaysian government decided to invest a massive amount of money to upgrade the capacity of seaports. This important decision has been made because Malaysian seaports will face tremendous constraint in terms of their capabilities in handling surplus containers from 2016 onwards (Containerisation, 2012). However, if we look at the berth utilization in Port Klang, Johor, Kuantan and Port of Tanjung Pelepas are underutilized (See Table 1). Thus, maximum utilisation of existing resources and adoption of the TQM is the best strategy to enhance the seaport performance.

Malaysian seaports have been able to achieve this higher efficiency due to continuous expenditure on quality management toward efficiency improvement in seaport terminal infrastructure, cargo handling technology and 
equipment, and seaport information technology. Thus, the TQM approach is important to play the role of performance in the Malaysia seaport (See Table 2).

Table 2.Malaysian Major Seaport Adopted ISO

\begin{tabular}{|c|c|c|c|}
\hline Port Klang & Johor Port & Penang Port & Kuantan Port \\
\hline $\begin{array}{l}1 . \quad \text { ISO } 14001 \\
\text { and } \\
2 . \quad \text { ISO 27001: } \\
2013 \text { (Environmental } \\
\text { management system } \\
\text { and information } \\
\text { security systems) }\end{array}$ & $\begin{array}{l}\text { 1. ISO 9001: } 2008 \\
\text { 3.Sirim 27001: } \\
\text { 2013(Standardization } \\
\text { procedure) } \\
\text { 4. ISO to ISO 55001:2014 } \\
\text { on (Asset management) } \\
\text { 5. ISO 14001 2009 } \\
\text { 6. OHSAS 18001: } 2007 \\
\text { (Occupational Safety and } \\
\text { Health Assessment). } \\
\text { 7. ISO 9001: } 2000 \text { Quality } \\
\text { Certification for Port } \\
\text { Management) }\end{array}$ & $\begin{array}{l}\text { 1. MS 9001:2008 } \\
\text { (Port Operations and } \\
\text { Management Services) } \\
\text { 2. MS 1900:2005, } \\
\text { MS 9001:2008 } \\
\text { (Provision of Container } \\
\text { Handling Service) }\end{array}$ & $\begin{array}{l}\text { 1. MS ISO 9001: } 2008 \\
\text { 2. ISMS ISO 27001: } 2013 . \\
\text { 3. MS ISO 9001: 2008, } \\
\text { (Dangerous cargo handling } \\
\text { operations) } \\
\text { 4. ISMS ISO 27001:2013 } \\
\text { (Information Security } \\
\text { Management System) }\end{array}$ \\
\hline
\end{tabular}

\section{Implications and conclusion}

Seaport capacity utilization is one of the indicators should be considered by policy maker for seaport expansion, underutilisation of existing seaport capacities will affect the internal operation of seaports and, at the same time, leave some obstructions on the external seaport network such as rail and intermodal terminal networks. Thus, the implementation of the TQM through seaport cluster is very important, in order to achieve quality seaport products and/or services, aTQM approach is required interrelating all those stakeholders in the seaport cluster (internally \& externally) which contribute (pilots, terminal operators, logistics and transport companies, intermediaries and service providers, warehousing firms etc) to seaport operations. TQM management paradigm place emphasis on customer (internal \& external) orientation, involving all seaport units, through the active involvement and empowermentof staff, and is based on a long-term commitment to the continuous improvement management paradigm.

In contrast, if the government continues to increase the capital expenditure on improvement in Malaysian seaports every five years, it will have a less positive impact on Malaysian seaport attractiveness among the shipping lines due to high seaport charges. Seaport charges will simultaneously increase with the amount of capital expenditure, because increasing seaport charges is the only appropriate approach for the seaport authorities to take when compensating for the cost, which has been invested earlier, this situation influences the attractiveness of Malaysian seaports to shipping lines.

Thus, the quality of seaport services is becoming a commercial asset, helping to retain customer loyalty and created harmonization in the seaport cluster, it also can help optimized the made of seaport facilities that are underutilized or poorly used for lack of coordination among the service provided by different entities during seaport operation.Therefore, rather than the Malaysian government allocating large amounts of money solely for capacity expansion, the same amount may be used to enhance the quality management of the seaport cluster and embedded the quality culture in the seaport cluster.From a researcher viewpoint, it is quite interesting to investigate the TQMparadigm in relation to the seaport cluster that may provide the best strategic approach for the seaports at present and in the future.

\section{References}

1. Alex, F. (2013), Something else for Singapore to brag about, Southeast Asia, Wall Street Journal.

2. Brodie, P. (2006). Commercial shipping handbook. (2 ${ }^{\text {nd }}$ Ed.) MPG books, bodmin, cornwall.

3. Containerisation, (2012), Top 100 ports, Informa Publication, London, ISSN: 0010-7379.

4. Chudasama, K. M. (2009). Performance appraisal of Indian major ports using port ranking model. The UIP Journal of Infrastructure. Vol. VII, No. 1.

5. Cullinane, K., Song, D. W. and Gray, R. (2002). A Stochastic Frontier Model of the Efficiency of Major Container Terminals in Asia: Assessing the Influence of Administrative and Ownership Structure.The Transportation Research part A: Policy and Practice, Vol. 36, pp. 743-762.

6. Estache, A., Gonzalez, M. M., and Trujillo, L. (2002). Efficiency gains from port reform and the potential for yardstick competition: lesson from Mexico. World Development, Vol. 30, pg. 545-560. 
7. Fourgeaud, P. (2000). Measuring port performance. The world Bank.

8. Ghaderi, H., Cahoon, S. and Nguyen, H-O. (2015a). The impediments to the competitiveness of rail in the Australian port-based container flow, Proceedings of the International Association of Maritime Economists Conference (IAME), Kuala Lumpur, Malaysia.

9. Ghaderi, H., Cahoon, S. and Nguyen, H-O. (2015b), An investigation into the non-bulk rail freight transport in Australia, The Asian Journal of Shipping and Logistics, vol. 31, no. 1, pp-59-83.

10. Hai Tran, Stephen Cahoon \& Shui Ling (2011), A Quality Management Framework for Seaport in their Supply Chain in the $21^{\text {st }}$ Century.

11. Ho, M. W., and David, K. H. (2006), Risk management in large physical infrastructure investments: The context of seaport infrastructure development and investment, Maritime Economics \& Logistics, Vol 8, No2, pp. 140-168.

12. Hyde, A. (1992). "The Proverbs of Total Quality Management: Recharting the Path to Quality Improvement in the Public Sector." Public Productivity and Management Review, 16(1), 25-37.

13. Johan Woxenius, Violeta Roso, Kenth Lumsden (2004), The Dry Port Concept - Connecting Seaports with their Hinterland by Rail.

14. Kim, S. Dinwoodie, J and Micheal, R. (2013), The impact of sustainability practices on competitiveness in Busan: A mega container port in northeast Asia, International Association of Maritime Economics (IAME) conference proceedings, Marseille France.

15. Kleywegt, A., Goh, M. L., Wu, G., and Zhang, H. (2002). Competition between the ports of Singapore and Malaysia. The Logistics Institute-Asia Pacific.

16. Kruger, V. (2001), Main Schools of TQM: The Big Five, The TQM Magazine, 13(3), pp. 146-155

17. Liu, Z. (1995). The comparative perfromance of public and private enterprises: The case of British ports. Journal of Transport Economics and policy, 29 (3),pg. 263-274.

18. Mak. J and. Bernard, K.M. (2001), Port development within the framework of Malaysia's transport policy: Some considerations, Maritime Policy \& Management, Vol.28, No 2, pp. 199-206.

19. Malaysia Freight Transport Report. (2012), Business monitor international industry survey \& forecasts series, Published by Business Monitor International Limited. ISSN 1752-5950, pp 14-15.

20. MIMA, Maritime Institute of Malaysia. (2013), http://www.mima.gov.my/mima/web- links/Malaysianports/minor-ports-and-jetties, Accessed on 21.09. 2014.

21. Nazery, K. (2007a), Enhancing maritime support services in Malaysia: A strategic approach, centre for economic studies and ocean industries, Maritime Institute of Malaysia.

22. Notteboom, T. (2004), Container shipping and ports: an overview. Review of network economics Vol.32, No.2, pp. 86-106.

23. Notteboom, T. and Rodrigue, J.P. (2008), The future of containerization: Perspectives from maritime and inland freight distribution. Geography Journal, Vol. 74, No.1, pp. 7-22.

24. Notteboom, T. (2006). The time factor in liner shipping services. Maritime economic \& Logistics. Vol. 8, pg. 19-39.

25. Notteboom, T. and Yap, W. Y. (2011), The interdependence between liner shipping networks and intermodal networks', Proceedings of the Conference of the International Association of Maritime Economists (IAME), Panama City.

26. Oakland, J.S. (1989), Total Quality Management, Heinemann, Oxford.

27. Porter, M. E., 1998. Competitive Advantage Creating and Sustaining Superior Performance. Bus. Rev., Free Press. (1).

28. Pun, K.F., Chin, K.S. \& Lau, H. (1999) A self-assessed quality management system based on the integration of MBQNA/ ISO 9000/ ISO 14000. International journal of quality \& reliability management, 16(6), pp.606-629

29. Rodrigue and Notteboom (2008), The terminalisation of supply chain," in Proceedings of the LAME 2008, Conference, Dailan China.

30. Saharuddin, A.H. (2001), National ocean policy-new opportunities for Malaysian ocean development. Marine Policy, Vol.25 (6), pp. 427-436.

31. Slack, Brian, Claude Comtois, and Robert Mccalla. (2002), Strategic alliances in the container shipping industry: A global perspective. Maritime Policy \& Management Vol. 29 No.1, pp.65-76.

32. Soon, C. and Lam, W.H. (2013), The growth of seaports in Peninsular Malaysia and East Malaysia for 2007-2011, Ocean \& Coastal Management, Vol.78, pp. 70-76.

33. Stephen J. Andrle (1994), Total Quality Management in Public Transportation

34. Tengku Jamaluddin (2003). Liberalization of the container haulage industry in Malaysia. Transport and communication bulletin for Asia and the Pacific. No. 73.

35. Tongzon, J.L. (2009). Port choice and freigh forwarders. Transportation research. Part E 45. Pg. 186195. 
The Sustainability Stimulus of Malaysian Seaport Cluster toward Competitive Vigilance: The Total Quality Management (TQM) Approach

36. UNESCAP.(2007), Regional Shipping and Port Development, Container Traffic Forecast, United Nations, New York.

37. Van Ham, J.C. (2005), The feasibility of mega container vessels. European Transport, Vol.4, No. 26, pp. 89-98.

38. Yeo, G. Roe, M. and Soak, S. M. (2007). Evaluation of the marine traffic congestion of north harbour in Busan port. Port Journal of waterway, port, coastal, and ocean engineering. Vol. 133, No. 2, pg. 87-93.

39. World Bank.(2013), in World Bank Port Reform Toolkit Modules 1-8, Washington D.C.

40. Yeo, G. Roe, M. and Soak, S. M. (2007). Evaluation of the marine traffic congestion of north harbour in Busan port. Port Journal of waterway, port, coastal, and ocean engineering. Vol. 133, No. 2, pg. 87-93.

41. Yusr, M.M., Mokhtar, S.S.M., Othman, A.R., Sulaiman, Y. (2017). Does interaction between TQM practices and knowledge management processes enhance the innovation performance?. International Journal of Quality and Reliability Management, 34 (7), pp. 955-974.

42. World Bank.(2013), in World Bank Port Reform Toolkit Modules 1-8, Washington D.C. 